\title{
Perioperative Nutrition in Elective Gastrointestinal Surgery - Potential for Improvement?
}

\author{
H. Akbarshahi B. Andersson M. Nordén R. Andersson \\ Department of Surgery, Clinical Sciences Lund, Lund University Hospital, Lund, Sweden
}

\section{Key Words}

Perioperative nutrition - Gastrointestinal surgery ·

Immunonutrition · Early feeding • Enteral nutrition •

Enteral feeding

\begin{abstract}
Nutritional concern is one of the most important issues to be addressed in the perioperative care given to gastrointestinal patients. Not at least, malnutrition may be detrimental and relate to postoperative morbidity. Perioperative nutritional management, integrated with other modern perioperative care policies, allows the establishment of multimodal strategies with an attempt to optimize the patients' course of disease. The present review evaluates available data regarding pre- and postoperative nutrition, nutritional supplements, including immunonutrition, and their clinical role. It is to be concluded that pre- and postoperative prolonged fasting has no routine role in management. Instead, for example, early postoperative feeding administered perorally or enterally may reduce postoperative complications and length of hospital stay. There are also indications that perioperative immunonutrition may reduce postoperative infectious complications and length of hospital stay, though further studies in this field are needed.

Copyright $\odot 2008$ S. Karger AG, Basel
\end{abstract}

\section{Introduction}

Despite important advances in surgical care and minimized surgical trauma, postoperative complications are still of great concern. Not at least, malnutrition is a wellknown cause of increased morbidity and mortality in surgical patients, and severe malnutrition may cause ongoing energy deficits in the postoperative period, resulting in an increased risk of infectious complications [1-4]. Gastrointestinal patients, especially with underlying malignancy, are at high risk of developing malnutrition, and surgical stress can also accentuate this catabolic problem.

In recent years, several traditionally accepted rules and 'truths' regarding perioperative nutritional cares have been challenged. The ultimate goals have not at least been to prevent malnutrition and its detrimental effects in favor of the patient and the healthcare system.

Reducing the length of pre- and postoperative fasting are among the issues that have drawn attention in more recent studies. Nutritional supplementation in the form of dietary supplementation and immunonutrition are other topics. The latter is a novel mode of intervention with the aim of decreasing infectious complications [5]. Data gathered from the above studies, beside other nonnutritional perioperative care policies, may form multimodal strategies resulting in improved clinical outcome [6].

\section{KARGER \\ Fax +4161306 1234 E-Mail karger@karger.ch} www.karger.com
Roland Andersson, MD, PhD

Department of Surgery, Clinical Sciences Lund

Lund University Hospital, SE-221 85 Lund (Sweden)

Tel. +46461723 59, Fax +4646147298

E-Mail roland.andersson@med.lu.se 
The present review aims at investigating reported data on different aspects of perioperative nutritional care and their role in patients undergoing elective gastrointestinal surgery, with a more detailed focus on immunonutrition.

\section{Early Postoperative Nutrition}

Postoperative management of patients after gastrointestinal surgery traditionally involved a period of 'nil by mouth' and nasogastric decompression in order to prevent postoperative nausea and vomiting and to protect an intestinal anastomosis. The fasting period continued until resolution of postoperative ileus, indicated by the passage of flatus and return of bowel sounds.

However, this type of management is not supported by scientific evidence [6-9]. On the contrary, experimental and clinical studies have demonstrated that early postoperative feeding increases strength and healing of an intestinal anastomosis [9-14]. Neither did a meta-analysis of 26 trials, including approximately 4,000 patients, support the routine use of nasogastric decompression in the postoperative period [15]. There are data reporting that early nutrition after surgery prevents an increase in gut mucosal permeability, produces a positive nitrogen balance, improves total calorie intake, and reduces infectious complications $[16,17]$.

When reviewing early versus late inserted postoperative enteral nutrition following colorectal surgery, no statistically significant difference in postsurgical complications was found, though early enteral feeding (within $24 \mathrm{~h}$ ) tended to be favorable $[18,19]$. Despite heterogeneity of the clinical studies evaluated, both reviews state the safety, feasibility and potential benefits (on postsurgical complications and the length of hospital stay) by early postoperative nutrition.

\section{Early Oral Feeding}

Early oral feeding after lower gastrointestinal surgery has been shown to be safe. It reduces the risk of any type of infection and the mean length of hospital stay [20-31].

Based on the rationale that laparoscopic colorectal surgery is minimally invasive with decreased bowel manipulation, some authors believe that early feeding can be better tolerated following this type of surgery. A limited number of studies have been performed concerning early enteral nutrition following open versus laparoscopic colorectal surgery. Overall, there seems to be no differ- ence when it comes to the tolerance of early enteral feeding when comparing open and laparoscopic surgery, and early enteral feeding is tolerated following both types of intervention [32-36].

In contrast to the quite numerous studies following colorectal procedures, less is known about the outcome of early oral nutrition following major upper gastrointestinal surgery [37]. Early oral feeding (within 48 h) following gastrectomy did not seem to increase morbidity and shortened the length of hospital stay [38-40]. When reviewing five prospective, randomized controlled clinical trials, totally including 333 patients, on early enteral nutrition following liver resection, this management was shown to be both safe and associated with a lower incidence of postoperative complications [37].

\section{Early Tube Feeding}

Initiation of early enteral feeding via a tube has proven to be beneficial, practicable and cost-effective in upper gastrointestinal surgery, as demonstrated in several studies [41-50]. Among beneficial effects, early enteral nutrition after upper gastrointestinal surgery prevents the otherwise occurring increase in gut permeability, the exaggerated inflammatory response following surgery, lipid oxidation, whole-body protein catabolism and pronounced perioperative weight loss [16, 50,51]. It should, however, also be mentioned that some studies have not shown any beneficial effect by routine early enteral nutrition in patients subjected to gastrointestinal surgery [5254]. In 195 patients undergoing upper gastrointestinal cancer surgery, the importance of patient selection was stressed in order to identify those actually in gain of early enteral nutrition [52]. Immediate postoperative jejunal feeding was also reported to be associated with impaired respiratory mechanics and postoperative mobility and no influence of early enteral feeding was found concerning loss of muscle strength or fatigue [54].

Early enteral nutrition can cause complications that are categorized as tube- and feeding-related adverse effects. Tube dislodgement, clogging, infection at the entry site, intestinal obstruction, small bowel necrosis, massive intestinal pneumatosis and intra-abdominal leakage of enteral feeding that can lead to death are all complications reported related to the use of jejunostomy tubes. Gastrointestinal adverse effects related to early nutrition are abdominal cramps, bloating, diarrhea, vomiting, delayed gastric emptying and aspiration [7, 41, 50, 55-57].

Braga et al. compared complications of jejunostomy and nasojejunal tubes in 650 patients who underwent major digestive surgery for cancer. They found similar 
rates of gastrointestinal adverse effects, but a higher rate of displacement and clogging following the use of nasojejunal tubes. The same authors reviewed 13 studies with nearly 5,000 cases and concluded that the overall jejunostomy-related complication rate was $2.9 \%$, ranging from 0.8 to $16 \%$, while the incidence of major complications (bowel necrosis, pneumatosis or obstruction) was less than $1.5 \%$ [7].

The recommendation is to start enteral tube feeding with a low flow rate (e.g. 10 to $\max .20 \mathrm{ml} / \mathrm{h}$ ), after which the target intake can be reached within 5-7 days [58]. Feeding jejunostomy tubes can also be used for the administration of medications and can also ascertain longer nutritional support required at home or during chemoradiotherapy $[7,41]$.

\section{Preoperative Oral Carbohydrate Loading}

Nutritional preoperative management has been challenged regarding the use of prolonged fasting prior to surgery. Among potential factors, the general rationale of preoperative fasting has been to prevent the risk of aspiration of gastric contents during the induction of anesthesia. However, convincing evidence has emerged and for example the administration of fluids perorally has not increased the risk of aspiration and therefore the traditional routine long preoperative fasting period previously practiced can no longer be recommended $[59,60]$.

A significant mechanism to be considered is the insulin resistance occurring during the postoperative period [61]. Carbohydrate-rich beverages have been found to be as safe as clear fluids even when administered shortly before elective surgery, and oral carbohydrates given prior to elective surgery reduce the otherwise occurring postoperative insulin resistance [62-65]. Several studies on preoperative oral carbohydrate loading in gastrointestinal surgery patients have shown beneficial effects also by reducing preoperative patient discomfort, preservation of skeletal muscle mass and strength and most likely also on postoperative nausea and vomiting [66-69]. However, in a randomized clinical study on 94 patients undergoing laparoscopic cholecystectomy, no difference was found when evaluating clinical improvements after surgery by oral carbohydrate administration, a lack of effect by the authors explained may be due to the less invasiveness of the type of surgery performed [70].

\section{Dietary Supplements}

Oral dietary supplements (Fortisip ${ }^{\circledR}$ ), providing 1.5 $\mathrm{kcal}, 0.05 \mathrm{~g}$ protein and $0.18 \mathrm{~g}$ carbohydrate per milliliter, have been studied in patients subjected to gastrointesti- nal surgery [71-73]. Smedly et al. [71] studied 152 patients undergoing lower gastrointestinal tract surgery, and randomized them into four groups with no nutritional supplements, perioperative supplements, only postoperative supplements, and only preoperative supplements, respectively. The authors concluded that perioperative oral nutritional supplementation significantly decreased weight loss and postoperative morbidity regardless of body mass index. Interestingly, the beneficial effects were not restricted to malnourished patients alone. Beneficial effects by postoperative oral dietary supplementation have also been noted during the inpatient phase with the prevention of infectious complications [72], weight loss and postoperative complications [73]. The routine use of perioperative oral dietary supplementation in well-nourished patients was, however, not found to be of any additional value [74].

\section{Immunonutrition}

The use of different nutrients in order to modulate the function of the immune system has become an important issue not at least in the management of patients undergoing gastrointestinal surgery. The different specific nutrients used in the various studies have included amino acids (arginine and glutamine), $\omega-3$ fatty acids and RNA nucleotides.

Glutamine. Glutamine is essential for protein and nucleotide synthesis. Increased metabolic demands of inflammation or injury lead to glutamine consumption, which is associated with progressive changes in intestinal morphology. Glutamine supplementation administered enterally can reverse the intestinal atrophy and prevent bacterial translocation [75]. Furthermore, glutamine seems to have effects on immune function and may decrease the inflammatory response and infectious complications [76, 77].

Arginine. Arginine is considered as a semi-essential amino acid, acting as an immunomodulator and with favorable effects in catabolic conditions such as severe sepsis and postoperative stress $[78,79]$. The role of postoperative arginine supplementation on immune, metabolic and endocrine parameters was studied in a randomized clinical trial in patients undergoing gastrointestinal cancer surgery. Faster recovery of immunologic parameters was seen during the postoperative period in the arginine group as compared to glycine-treated patients [80]. Arginine supplementation has also been reported to improve wound healing and improve phagocytic ability and respiratory burst of polymorphonuclear monocytes, most likely due to increased levels of nitric oxide [81]. 
$\omega-3$ Fatty Acids. $\omega-3$ fatty acids replace arachidonic acid in cell membranes and modulate immune function [81]. They alter the formation of prostaglandin $\mathrm{E}_{2}$ to prostaglandin $\mathrm{E}_{3}$, which has a less immunosuppressive effect [82]. The use of these fatty acids has been reported to decrease the total number of gastrointestinal and infectious complications and improve postoperative liver and kidney function through modulation of tissue prostaglandin levels $[83,84]$.

Nucleotides. The value of supplemental nucleotides has been studied to a less degree but they seem essential for cell-mediated immunity and helper/inducer T-lymphocyte function [75].

\section{Clinical Outcome of Immunonutrition}

The most common reported beneficial effects of immunonutrition are reductions in the rate of postoperative infectious complications and the length of hospital stay [43, 46, 85-98]. Moreover, a reduction in stoma fistula and improved surgical wound healing are other favorable outcomes reported $[92,99]$. Some studies have also shown a cost-effectiveness of immunonutritional administration, related to the reduction in postoperative infectious complications and length of hospital stay [87, 90, 100].

In 32 patients undergoing liver transplantation, preand postoperative immunonutrition reduced the incidence of postoperative infectious complications, though this study was not a randomized clinical trial [101]. Not all studies, though, have been able to demonstrate any significant advantage of immunonutrition [52, 102-105]. A summary of data from randomized clinical trials on immunonutrition in elective gastrointestinal surgery is presented in table 1.

\section{Laboratory Outcomes}

Immunomodulatory effects have been observed following immunonutrition regarding both cellular and humoral immunity, phagocytic ability, levels of plasma proteins and inflammatory mediators. Among the effects observed are increase in the mean total lymphocyte count [103], cell-mediated immune response, activated T lymphocytes, CD4 expression [92, 104], IL-2 expression [106, 107], plasma levels of IL-2 and CD4/CD8 ratio [98, 106, 108], B-lymphocyte indices, interferon- $\gamma$, and immunoglobulins $\mathrm{G}$ and $\mathrm{M}[92,104]$.

In patients undergoing elective surgery for colorectal cancer, preoperative immune-enhanced nutritional supplementation corrected the Th1/Th2 balance [109]. Other effects are the prevention of early postoperative decrease of both phagocytic ability and respiratory burst of polymorphonuclear cells $[81,93,98,108]$ and improvement in delayed hypersensitivity responses $[93,106]$.

Immunonutrition also reduces levels of inflammatory markers measured like C-reactive protein (CRP), tumor necrosis factor- $\alpha$ (TNF- $\alpha$ ) and endotoxin $[81,105]$, and acute phase mediators (TNF- $\alpha$, CRP and IL- 6 ) $[81,92,98$, 106-108] postoperatively.

Preoperative administration of immunonutrition $\left(\right.$ Impact ${ }^{\circledR}$ ) in patients undergoing upper gastrointestinal cancer surgery resulted in a significant increase in levels of eicosapentaenoic acid, docosahexaenoic acid, and total $\omega-3$ fatty acids, while levels of linoleic acid, arachidonic acid, and thromboxane $\mathrm{B}_{2}$ decreased significantly [110]. Other studies have shown an increase in plasma and peripheral white blood cell $\omega-3 / \omega-6$ ratio, but decreased $\mathrm{PGE}_{2}$ production $[85,111]$. Furthermore, immunonutrition has been reported to result in an increase in nitric oxide plasma concentrations [98, 108], local hydroxyproline production [99], and serum concentrations of prealbumin and retinol-binding protein $[93,111]$. Moreover, immunonutrition causes improved intestinal microperfusion and improved postoperative gut mucosal oxygen metabolism $[98,108]$.

\section{Immunonutrition Administered in Upper or \\ Lower Gastrointestinal Tract Surgery}

In the majority of randomized clinical trials performed, the impact of immunonutrition has been studied in upper gastrointestinal tract cancer patients, a category of patients with more malnourishment and difficulties with nutrition. However, it has been implied that the impact of immunonutrition could be similar in the whole gastrointestinal tract, thus including also patients with lower gastrointestinal tract cancer surgery $[86,88,89,91$, 98].

\section{Pre-, Post- or Perioperative Administration of \\ Immunonutrition?}

Historically, the first RCTs were designed to study the effects of postoperative supplemental diet. Later on, due to the rationale that the effects of surgical stress occur immediately as a response to the surgical trauma, studies were planned to record the impact of preoperative administration of immunonutrients [112]. In three studies, pre- and perioperative administration of immunonutrition was compared and no significant differences were found regarding the clinical outcome $[86,88,89]$. A reduction in postoperative infection and the occurrence of stoma fistula have been reported in a study comparing preoperative immunonutrition with controls without 
Table 1. Randomized clinical trials of immunonutrition in elective gastrointestinal surgery

\begin{tabular}{|c|c|c|c|c|c|c|c|c|}
\hline $\begin{array}{l}\text { Group } \\
\text { [Ref.] }\end{array}$ & $\begin{array}{l}\mathrm{Pa}- \\
\text { tients }\end{array}$ & $\begin{array}{l}\text { Upper/ } \\
\text { lower/ } \\
\text { whole GI }\end{array}$ & $\begin{array}{l}\text { Pre-/post-/ } \\
\text { peri- } \\
\text { operative }\end{array}$ & Groups and diets & $\begin{array}{l}\text { Optimal } \\
\text { dose }\end{array}$ & Number of days & Clinical outcome & Comments \\
\hline $\begin{array}{l}\text { Daly } \\
{[95]}\end{array}$ & 85 & $\begin{array}{l}\text { Upper } \\
\text { GI }\end{array}$ & $\begin{array}{l}\text { Post- } \\
\text { operative }\end{array}$ & $\begin{array}{l}2 \text { groups } \\
\text { Impact } \\
\text { Standard }\end{array}$ & $75-100 \mathrm{ml} / \mathrm{h}$ & First POD, discharge & $\begin{array}{l}\text { Reduced postoperative } \\
\text { infection, wound } \\
\text { complications and length } \\
\text { of hospital stay }\end{array}$ & $\begin{array}{l}\text { Low-protein } \\
\text { control diet; more } \\
\text { esophagectomy and } \\
\text { pancreatomy in } \\
\text { control group }\end{array}$ \\
\hline $\begin{array}{l}\text { Daly } \\
{[85]}\end{array}$ & 60 & $\begin{array}{l}\text { Upper } \\
\text { GI }\end{array}$ & $\begin{array}{l}\text { Post- } \\
\text { operative }\end{array}$ & $\begin{array}{l}4 \text { groups } \\
\text { Impact (inpatient) } \\
\text { Impact (in- and outpatient) } \\
\text { Standard (inpatient) } \\
\text { Standard (in- and } \\
\text { outpatient) }\end{array}$ & $75-100 \mathrm{ml} / \mathrm{h}$ & $\begin{array}{l}\text { Inpatient: first POD, } \\
\text { discharge } \\
\text { Outpatient: first POD } \\
\text { 12-16 weeks after } \\
\text { discharge }\end{array}$ & $\begin{array}{l}\text { Reduced postoperative } \\
\text { infection, wound } \\
\text { complications and length } \\
\text { of hospital stay }\end{array}$ & \\
\hline $\begin{array}{l}\text { Senkal } \\
{[87]}\end{array}$ & 154 & $\begin{array}{l}\text { Upper } \\
\text { GI }\end{array}$ & $\begin{array}{l}\text { Post- } \\
\text { operative }\end{array}$ & $\begin{array}{l}2 \text { groups } \\
\text { Impact } \\
\text { Standard }\end{array}$ & $80 \mathrm{ml} / \mathrm{h}$ & $\begin{array}{l}12 \mathrm{~h} \text { after surgery, } \\
\text { discharge }\end{array}$ & $\begin{array}{l}\text { Reduced late postoperative } \\
\text { infection (after POD 5) } \\
\text { Reduced overall costs for } \\
\text { complication treatment }\end{array}$ & $\begin{array}{l}\text { Not intention-to- } \\
\text { treat study }\end{array}$ \\
\hline $\begin{array}{l}\text { Helsin } \\
{[52]}\end{array}$ & 195 & $\begin{array}{l}\text { Upper } \\
\text { GI }\end{array}$ & $\begin{array}{l}\text { Post- } \\
\text { operative }\end{array}$ & $\begin{array}{l}2 \text { groups } \\
\text { Impact } \\
\text { IV crystalloid }\end{array}$ & 1 1/day & $\begin{array}{l}\text { Within } 24 \mathrm{~h} \text { after } \\
\text { surgery, discharge }\end{array}$ & $\begin{array}{l}\text { Early enteral feeding was } \\
\text { not beneficial }\end{array}$ & \\
\hline $\begin{array}{l}\text { Schilling } \\
\text { [103] }\end{array}$ & 48 & $\begin{array}{l}\text { Whole } \\
\text { GI }\end{array}$ & $\begin{array}{l}\text { Post- } \\
\text { operative }\end{array}$ & $\begin{array}{l}3 \text { groups } \\
\text { Impact } \\
\text { Standard (Fresubin) } \\
\text { IV solution }\end{array}$ & 1 1/day & $\begin{array}{l}\text { Within } 24 \mathrm{~h} \text { after } \\
\text { surgery, discharge }\end{array}$ & $\begin{array}{l}\text { Early enteral feeding was } \\
\text { not beneficial }\end{array}$ & \\
\hline $\begin{array}{l}\text { Braga } \\
{[43,46,} \\
93,94 \\
96,97]\end{array}$ & * & $\begin{array}{l}\text { Upper } \\
\text { GI }\end{array}$ & $\begin{array}{l}\text { Post- } \\
\text { operative }\end{array}$ & $\begin{array}{l}3 \text { groups } \\
\text { Impact } \\
\text { Standard } \\
\text { TPN }\end{array}$ & $\begin{array}{l}25 \mathrm{kcal} / \mathrm{kg} / \\
\text { day }\end{array}$ & $\begin{array}{l}\text { Within } 12 \mathrm{~h} \text { after } \\
\text { surgery, discharge }\end{array}$ & $\begin{array}{l}\text { Reduced severity of } \\
\text { infection and length of } \\
\text { hospital stay compared to } \\
\text { TPN group }\end{array}$ & \\
\hline $\begin{array}{l}\text { Braga } \\
{[91,98]}\end{array}$ & $*$ & $\begin{array}{l}\text { Whole } \\
\text { GI }\end{array}$ & $\begin{array}{l}\text { Peri- } \\
\text { operative }\end{array}$ & $\begin{array}{l}2 \text { groups } \\
\text { Impact } \\
\text { Standard }\end{array}$ & $11 /$ day & $\begin{array}{l}7 \text { days before surgery } \\
\text { POD } 7\end{array}$ & $\begin{array}{l}\text { Reduced postoperative } \\
\text { infections and length of } \\
\text { hospital stay }\end{array}$ & \\
\hline $\begin{array}{l}\text { Braga } \\
{[88]}\end{array}$ & 200 & $\begin{array}{l}\text { Lower } \\
\text { GI }\end{array}$ & $\begin{array}{l}\text { Peri- } \\
\text { operative }\end{array}$ & $\begin{array}{l}4 \text { groups } \\
\text { Impact (preoperative) } \\
\text { Impact (perioperative) } \\
\text { Standard (preoperative) } \\
\text { No supplementation }\end{array}$ & 1 1/day & $\begin{array}{l}\text { Pre: } 5 \text { days before } \\
\text { surgery } \\
\text { Peri: } 5 \text { days before } \\
\text { surgery, discharge }\end{array}$ & $\begin{array}{l}\text { Reduced postoperative } \\
\text { infections and length of } \\
\text { hospital stay, but no } \\
\text { significant difference } \\
\text { between pre- and } \\
\text { perioperative groups }\end{array}$ & \\
\hline $\begin{array}{l}\text { Braga } \\
{[89]}\end{array}$ & 150 & $\begin{array}{l}\text { Whole } \\
\text { GI }\end{array}$ & $\begin{array}{l}\text { Peri- } \\
\text { operative }\end{array}$ & $\begin{array}{l}3 \text { groups } \\
\text { Impact (preoperative) } \\
\text { Impact (perioperative) } \\
\text { Standard (postoperative) }\end{array}$ & 1 1/day & $\begin{array}{l}\text { Pre: } 7 \text { days before } \\
\text { surgery } \\
\text { Peri: } 7 \text { days before } \\
\text { surgery, POD } 7\end{array}$ & $\begin{array}{l}\text { Reduced postoperative } \\
\text { complications and length } \\
\text { of hospital stay comparing } \\
\text { perioperative and control } \\
\text { groups }\end{array}$ & $\begin{array}{l}\text { Malnourished } \\
\text { (weight loss } \geq 10 \% \text { ) }\end{array}$ \\
\hline $\begin{array}{l}\text { Gianotti } \\
{[86]}\end{array}$ & 305 & $\begin{array}{l}\text { Whole } \\
\text { GI }\end{array}$ & $\begin{array}{l}\text { Peri- } \\
\text { operative }\end{array}$ & $\begin{array}{l}3 \text { groups } \\
\text { Impact (preoperative) } \\
\text { impact (perioperative) } \\
\text { Standard (perioperative) }\end{array}$ & 1 1/day & $\begin{array}{l}\text { Pre: } 5 \text { days before } \\
\text { surgery } \\
\text { Peri: } 5 \text { days before } \\
\text { surgery, oral food } \\
\text { initiation }\end{array}$ & $\begin{array}{l}\text { Reduced postoperative } \\
\text { infections in normal, } \\
\text { overweight and obese } \\
\text { patients } \\
\text { Preoperative supplemen- } \\
\text { tation is as effective as } \\
\text { perioperative approach }\end{array}$ & Weight loss $\leq 10 \%$ \\
\hline $\begin{array}{l}\text { Kemen } \\
{[104]}\end{array}$ & 42 & $\begin{array}{l}\text { Upper } \\
\text { GI }\end{array}$ & $\begin{array}{l}\text { Post- } \\
\text { operative }\end{array}$ & $\begin{array}{l}2 \text { groups } \\
\text { Impact } \\
\text { Standard }\end{array}$ & $80 \mathrm{ml} / \mathrm{h}$ & POD 1-POD 10 & $\begin{array}{l}\text { No significant clinical } \\
\text { outcome }\end{array}$ & \\
\hline $\begin{array}{l}\text { Senkal } \\
{[90]}\end{array}$ & 154 & $\begin{array}{l}\text { Upper } \\
\text { GI }\end{array}$ & $\begin{array}{l}\text { Peri- } \\
\text { operative }\end{array}$ & $\begin{array}{l}2 \text { groups } \\
\text { Impact } \\
\text { Standard }\end{array}$ & $80 \mathrm{ml} / \mathrm{h}$ & $\begin{array}{l}\text { Peri: } 5 \text { days before } \\
\text { surgery, POD } 10\end{array}$ & $\begin{array}{l}\text { Reduced postoperative } \\
\text { infectious complications } \\
\text { Reduced overall costs for } \\
\text { complication treatment }\end{array}$ & $\begin{array}{l}\text { Not intention-to- } \\
\text { treat study }\end{array}$ \\
\hline
\end{tabular}


Table 1 (continued)

\begin{tabular}{|c|c|c|c|c|c|c|c|c|}
\hline $\begin{array}{l}\text { Group } \\
\text { [Ref.] }\end{array}$ & $\begin{array}{l}\mathrm{Pa}- \\
\text { tients }\end{array}$ & $\begin{array}{l}\text { Upper/ } \\
\text { lower/ } \\
\text { whole GI }\end{array}$ & $\begin{array}{l}\text { Pre-/post-/ } \\
\text { peri- } \\
\text { operative }\end{array}$ & Groups and diets & $\begin{array}{l}\text { Optimal } \\
\text { dose }\end{array}$ & Number of days & Clinical outcome & Comments \\
\hline $\begin{array}{l}\text { Giger } \\
{[105]}\end{array}$ & 46 & $\begin{array}{l}\text { Upper } \\
\text { GI }\end{array}$ & $\begin{array}{l}\text { Peri- } \\
\text { operative }\end{array}$ & $\begin{array}{l}3 \text { groups } \\
\text { Impact (preoperative) } \\
\text { Impact plus (preoperative) } \\
\text { Control (no supplements) } \\
\text { All } \rightarrow \text { postoperative impact }\end{array}$ & $80 \mathrm{ml} / \mathrm{h}$ & $\begin{array}{l}\text { Pre: impact: } 5 \text { days, } \\
\text { impact plus: } 2 \text { days } \\
\text { Post: } 7 \text { days }\end{array}$ & $\begin{array}{l}\text { No significant clinical } \\
\text { outcome }\end{array}$ & \\
\hline $\begin{array}{l}\text { Dileep } \\
{[102]}\end{array}$ & 108 & $\begin{array}{l}\text { Upper } \\
\text { GI }\end{array}$ & $\begin{array}{l}\text { Post- } \\
\text { operative }\end{array}$ & $\begin{array}{l}2 \text { groups } \\
\text { Stresson } \\
\text { Nutrison high protein }\end{array}$ & $75 \mathrm{ml} / \mathrm{h}$ & $\begin{array}{l}4 \mathrm{~h} \text { after surgery, } \\
\text { discharge }\end{array}$ & $\begin{array}{l}\text { No significant clinical } \\
\text { outcome }\end{array}$ & \\
\hline $\begin{array}{l}\text { Farreras } \\
\text { [99] }\end{array}$ & 60 & $\begin{array}{l}\text { Upper } \\
\text { GI } \\
\text { (gastric } \\
\text { cancer) }\end{array}$ & $\begin{array}{l}\text { Post- } \\
\text { operative }\end{array}$ & $\begin{array}{l}2 \text { groups } \\
\text { Impact } \\
\text { Isosource protein }\end{array}$ & $\begin{array}{l}\text { According to } \\
\text { the caloric } \\
\text { requirements }\end{array}$ & $\begin{array}{l}12-18 \mathrm{~h} \text { after surgery, } \\
\text { POD } 7\end{array}$ & $\begin{array}{l}\text { Improved surgical wound } \\
\text { healing }\end{array}$ & \\
\hline $\begin{array}{l}\mathrm{Xu} \\
{[92]}\end{array}$ & 60 & $\begin{array}{l}\text { Whole } \\
\text { GI }\end{array}$ & $\begin{array}{l}\text { Pre- } \\
\text { operative }\end{array}$ & $\begin{array}{l}2 \text { groups } \\
\text { Impact } \\
\text { Standard }\end{array}$ & $\begin{array}{l}25 \mathrm{kcal} / \\
\mathrm{kg} / \mathrm{day}\end{array}$ & 7 days before surgery & $\begin{array}{l}\text { Reduced postoperative } \\
\text { infection and stoma fistula }\end{array}$ & \\
\hline
\end{tabular}

GI = Gastrointestinal; POD = postoperative day. ${ }^{*}$ There are some patients included in more than one article.

immunonutrition [92]. Preoperative immunonutrition is now recommended (ESPEN Guidelines) in patients with elective gastrointestinal cancer surgery [58].

Oral Impact ${ }^{\circledR}$ has been the most commonly used formula studied. The optimal goal set was 1 liter/day or 75$80 \mathrm{ml} / \mathrm{h}$. The energy goal was $25 \mathrm{kcal} / \mathrm{kg} / \mathrm{day}$. In general, this goal can be achieved after a few days postoperatively, mostly 3-5 days.

Available data suggests that immunonutrition may be of benefit when administered preoperatively in elective gastrointestinal cancer patients and in trauma patients [113]. Some authors have emphasized patient selection in order to identify those who would gain more advantage from supplemental immunonutrition like malnourished patients [52], though Braga et al. [86] stressed the fact that regardless of the baseline nutritional status, perioperative immunonutrition was efficacious and well-nourished patients may also have some beneficial effects from immunomodulating diets.

\section{Discussion}

Traditional perioperative nutritional management in patients undergoing elective gastrointestinal surgery has merely been based on tradition - rather than on strict evidence-based fundaments. Thus, available data do not support the routine use of nasogastric decompression in the postoperative period, and neither is there any clinical benefit from keeping patients starved after surgery [114]. Instead, early institution of postoperative oral or enteral nutrition is both safe and beneficial, though additional studies especially regarding early oral nutrition following upper gastrointestinal surgery are needed. Furthermore, a prolonged period of fasting prior to surgery is not accepted anymore. The administration of preoperative oral carbohydrates is safe and can be done without fear of increasing risk of aspiration and among other effects prevents postoperative insulin resistance.

Different immunonutrients have been used in order to modulate immune function and shown beneficial both when used in trauma and elective surgical patients. However, the use of immunonutrition in critically ill patients should be selective in order to avoid potential harmful effects as has been described in this category of patients [115-119].

In nearly all studies performed, an immunonutritional diet was compared with isocaloric and isonitrogenous standard enteral diets. Perioperative administration of immunoenhancing diets reduced postoperative infections both in well-nourished and malnourished patients.

Administration of a preoperative diet may be optimal both clinically and economically for well-nourished patients, though perioperative use of nutritional supplementation seemed to be more clinically beneficial than 
the preoperative intervention in malnourished patients [100]. Nutritional support has a better impact in reducing infectious than non-infectious complications. Immune modulators can positively influence on the association between immune suppression and postoperative infections. These findings also point towards the surgical trauma and the related 'stress' is a risk factor for immune suppression leading to postoperative infections regardless of the basal nutritional status [120].

Overall, old traditions have been challenged and new, more evidence-based recommendations and guidelines have appeared. As important is, however, the compliance with newly set guidelines. So, for example, non-compliance with evidence-based practice regarding perioperative nutrition and routines among colorectal surgeons in different centers in five northern European countries and heterogeneous policies in postoperative nutritional support and oral intake could be found [121, 122].

Fast-track surgery has been developed and gained increasing popularity and used with benefits for both patients and healthcare providers. Multimodal strategies including minimal invasive surgery, nutritional care, anesthesia, enforced mobilization and other measures have resulted in reduction in morbidity and length of hospital stay [123-126]. Therefore, nutritional management plays a great role in the fast-track surgery concept.

There still are issues to clarify regarding perioperative nutrition in elective gastrointestinal surgery. The effects of early oral feeding in upper gastrointestinal surgery, the role of nucleotides in supplemental diets, and the effects of immunonutrition in lower gastrointestinal surgery are among these issues. There are also some concerns in designing the clinical studies. Immunomodulators are beneficial when patients receive the critical minimum amount of them. This is a crucial issue, since many of the studies failed to identify and reach this minimal but 'beneficial' amount. The patient groups should also be stratified according to the severity of their underlying disease and type of surgery they are going to be subjected to.

In conclusion, preoperative carbohydrate administration, the use of postoperative early feeding, and also perioperative immunonutrition are beneficial policies to be used in association with elective gastrointestinal surgery. The inclusion of novel evidence-based information in recommendations and guidelines, and not at least the compliance with these, are of outmost importance, all in favor of our patients. There is a potential for improvement!

\section{References}

- 1 Saluja SS, Kaur N, Shrivastava UK: Enteral nutrition in surgical patients. Surg Today 2002;32:672-678.

2 Powell-Tuck J: Perioperative nutritional support: does it reduce hospital complications or shorten convalescence? Gut 2000;46:749750 .

-3 Bengmark S, Andersson R, Mangiante G: Uninterrupted perioperative enteral nutrition. Clin Nutr 2001;20:11-19.

4 Ward N: Nutrition support to patients undergoing gastrointestinal surgery. Nutr J 2003;2:18.

5 Kirk HJ, Heys SD: Immunonutrition. Br J Surg 2003;90:1459-1460

6 Kehlet H, Wilmore DW: Multimodal strategies to improve surgical outcome. Am J Surg 2002;183:630-641.

-7 Braga M, Gianotti L, Gentilini O, Liotta S, Di $\mathrm{CV}$ : Feeding the gut early after digestive surgery: results of a nine-year experience. Clin Nutr 2002;21:59-65.

-8 Bisgaard T, Kehlet H: Early oral feeding after elective abdominal surgery - what are the issues? Nutrition 2002;18:944-948.
-9 Lewis SJ, Egger M, Sylvester PA, Thomas S: Early enteral feeding versus 'nil by mouth' after gastrointestinal surgery: systematic review and meta-analysis of controlled trials. BMJ 2001;323:773-776.

10 Schroeder D, Gillanders L, Mahr K, Hill GL Effects of immediate postoperative enteral nutrition on body composition, muscle function, and wound healing. J Parenter Enteral Nutr 1991;15:376-383.

11 Moss G: Maintenance of gastrointestinal function after bowel surgery and immediate enteral full nutrition. Clinical experience, with objective demonstration of intestinal absorption and motility. J Parenter Enteral Nutr 1981;5:215-220.

12 Fukuzawa J, Terashima H, Ohkohchi N: Early postoperative oral feeding accelerates upper gastrointestinal anastomotic healing in the rat model. World J Surg 2007;31:12341239.

-13 Demetriades H, Botsios D, Kazantzidou D, Sakkas L, Tsalis K, Manos K, Dadoukis I: Effect of early postoperative enteral feeding on the healing of colonic anastomoses in rats. Eur Surg Res 1999;31:57-63.
14 Udén P, Blomquist P, Jiborn H, Zederfeldt B: Impact of longterm relative bowel rest on conditions for colonic surgery. Am J Surg 1988;156:381-385.

15 Cheatham ML, Chapman WC, Key SP, Sawyers JL: A meta-analysis of selective versus routine nasogastric decompression after elective laparotomy. Ann Surg 1995;221: 469-476.

16 Carr CS, Ling KD, Boulos P, Singer M: Randomised trial of safety and efficacy of immediate postoperative enteral feeding in patients undergoing gastrointestinal resection. BMJ 1996;312:869-871.

$\checkmark 17$ Beier-Holgersen R, Boesby S: Influence of postoperative enteral nutrition on postsurgical infections. Gut 1996;39:833-835.

18 Andersen HK, Lewis SJ, Thomas S: Early enteral nutrition within 24 hours of colorectal surgery versus later commencement of feeding for postoperative complications. Cochrane Database Syst Rev 2006;18: CD004080.

19 Ng WQ, Neill J: Evidence for early oral feeding of patients after elective open colorectal surgery: a literature review. J Clin Nurs 2006; 15:696-709. 
20 Henriksen MG, Hansen HV, Hessov I: Early oral nutrition after elective colorectal surgery. Influence of balanced analgesia and enforced mobilization. Nutrition 2002;18:263267.

-21 DiFronzo LA, Yamin N, Patel K, O’Connell TX: Benefits of early feeding and early hospital discharge in elderly patients undergoing open colon resection. J Am Coll Surg 2003;197:747-752.

-22 Kawamura YJ, Uchida H, Wantanabe T, Nagawa $\mathrm{H}$ : Early feeding after oncological colorectal surgery in Japanese patients. J Gastroenterol 2000;35:524-527.

23 Choi J, O'Connell TX: Safe and effective early postoperative feeding and hospital discharge after open colon resection. Am Surg 1996;62:853-856

24 Petrelli NJ, Cheng C, Driscoll D, RodriguezBigas MA: Early postoperative oral feeding after colectomy: an analysis of factors that may predict failure. Ann Surg Oncol 2001;8: 796-800.

-25 Zhou T, Wu XT, Zhou YJ, Huang X, Fan W, Li YC: Early removing gastrointestinal decompression and early oral feeding improve patients' rehabilitation after colorectostomy. World J Gastroenterol 2006;12:2459-2463.

-26 Fearon KC, Ljungqvist O, von Meyenfeldt M, Revhaug A, Dejong CH, Lassen K, Nygren J, Hausel J, Soop M, Andersen J, Kehlet H: Enhanced recovery after surgery: a consensus review of clinical care for patients undergoing colonic resection. Clin Nutr 2005;24: 466-477.

27 Di Fronzo LA, Cymerman J, O’Connell TX: Factors affecting early postoperative feeding following elective open colon resection. Arch Surg 1999;134:941-945; discussion 945946.

-28 Reissman P, Teoh TA, Cohen SM, Weiss EG, Nogueras JJ, Wexner SD: Is early oral feeding safe after elective colorectal surgery? A prospective randomised trial. Ann Surg 1995; 222:73-77.

29 Ortiz H, Armendariz P, Yarnoz C: Is early postoperative feeding feasible in elective colon and rectal surgery? Int J Colorectal Dis 1996;11:119-121.

-30 Stewart BT, Woods RJ, Collopy BT, Fink RJ, Mackay JR, Keck JO: Early feeding after elective open colorectal resections: a prospective randomized trial. Aust NZ J Surg 1998;68: 125-128.

-31 Hartsell PA, Frazee RC, Harrison JB, Smith RW: Early postoperative feeding after elective colorectal surgery. Arch Surg 1997;132: 518-521.

\$2 Ortiz H, Armendariz P, Yarnoz C: Early postoperative feeding after elective colorectal surgery is not a benefit unique to laparoscopy-assisted procedures. Int J Colorectal Dis 1996;11:246-249.

- 33 Sands DR, Wexner SD: Nasogastric tubes and dietary advancement after laparoscopic and open colorectal surgery. Nutrition 1999; $15: 347-350$
-34 Binderow SR, Cohen SM, Wexner SD, Nogueras JJ: Must early postoperative oral intake be limited to laparoscopy? Dis Colon Rectum 1994;37:584-589.

35 Ramos J, Beart R, Goes R, Ortega A, Schlinkert R: Role of laparoscopy in colorectal surgery. A prospective evaluation of 200 cases. Dis Colon Rectum 1995;38:494-501.

36 Bruce CJ, Coller JA, Murray JJ, Schoetz DJ Jr Roberts PL, Rusin LC: Laparoscopic resection for diverticular disease. Dis Colon Rectum 1996;39(suppl 10):S1-S6.

-37 Richter B, Schmandra TC, Golling M, Bechstein WO: Nutritional support after open liver resection: a systematic review. Dig Surg 2006;23:139-145.

38 Lassen K, Revhaug A: Early oral nutrition after major upper gastrointestinal surgery: why not? Curr Opin Clin Nutr Metab Care 2006;9:613-617.

39 Suehiro T, Matsumata T, Shikada Y, Sugimachi K: Accelerated rehabilitation with early postoperative oral feeding following gastrectomy. Hepatogastroenterology 2004; 51 : 1852-1855.

-40 Hirao M, Tsujinaka T, Takeno A, Fujitani K Kurata M: Patient-controlled dietary schedule improves clinical outcome after gastrectomy for gastric cancer. World J Surg 2005; 29:853-857.

41 Chin KF, Townsend S, Wong W, Miller GV: A prospective cohort study of feeding needle catheter jejunostomy in an upper gastrointestinal surgical unit. Clin Nutr 2004;23: 691-696.

42 Aiko S, Yoshizumi Y, Sugiura Y, Matsuyama T, Naito Y, Matsuzaki J, Maehara T: Beneficial effects of immediate enteral nutrition after esophageal cancer surgery. Surg Today 2001;31:971-978.

43 Di Carlo V, Gianotti L, Balzano G, Zerbi A, Braga M: Complications of pancreatic surgery and the role of perioperative nutrition. Dis Surg 1999;16:320-326.

44 McCarter MD, Gomez ME, Daly JM: Early postoperative enteral feeding following major upper gastrointestinal surgery. J Gastrointest Surg 1996;1:278-285.

45 Fairfull-Smith RJ, Freeman JB: Immediate postoperative enteral nutrition with a nonelemental diet. J Surg Res 1980;29:236-239.

46 Braga M, Gianotti L, Vignali A, Cestari A, Bisagni P, Di Carlo V: Artificial nutrition after major abdominal surgery: Impact of route of administration and composition of the diet. Crit Care Med 1998;26:24-30.

47 Velez JP, Lince LF, Restrepo JI: Early enteral nutrition in gastrointestinal surgery: a pilot study. Nutrition 1997;13:442-445.

48 Mercer CD, Mungara A: Enteral feeding in esophageal surgery. Nutrition 1996;12:200201.

-49 Page RD, Oo AY, Russell GN, Pennefather SH: Intravenous hydration versus naso-jejunal enteral feeding after esophagectomy: a randomised study. Eur J Cardiothor Surg 2002;22:666-672.
50 Ryan AM, Rowley SP, Healy LA, Flood PM, Ravi N, Reynolds JV: Post-oesophagectomy early enteral nutrition via a needle catheter jejunostomy: 8-year experience at a specialist unit. Clin Nutr 2006;25:386-393.

51 Hochwald SN, Harrison LE, Heslin MJ, Burt ME, Brennan MF: Early postoperative enteral feeding improves whole body protein kinetics in upper gastrointestinal cancer patients. Am J Surg 1997;174:325-330.

-52 Heslin MJ, Latkany L, Leung D, Brooks AD, Hochwald SN, Pisters PW, Shike M, Brennan MF: A prospective, randomized trial of early enteral feeding after resection of upper gastrointestinal malignancy. Ann Surg 1997; 226:567-577.

53 Torosian MH: Perioperative nutrition support for patients undergoing gastrointestinal surgery: critical analysis and recommendations. World J Surg 1999;23:565-569.

54 Watters JM, Kirkpatrick SM, Norris SB, Shamii FM, Wells GA: Immediate postoperative enteral feeding results in impaired respiratory mechanics and decreased mobility. Ann Surg 1997;226:369-377.

55 Martignoni ME, Friess H, Sell F, Ricken L, Shrikhande S, Kulli C, Büchler MW: Enteral nutrition prolongs delayed gastric emptying in patients after Whipple resection. Am J Surg 2000;180:18-23.

56 Dominioni L, Rovera F, Pericelli A, Imperatori A: The rationale of early enteral nutrition. Acta Biomed 2003;74(suppl 2):41-44.

57 Yagi M, Hashimoto T, Nezuka H, Ito H, Tani T, Shimizu K, Miwa K: Complications associated with enteral nutrition using catheter jejunostomy after oesophagectomy. Surg Today 1999;29:214-218.

58 Weimann A, Braga M, Harsanyi L, Laviano A, Ljungqvist $\mathrm{O}$, Soeters $\mathrm{P}$ (DGEM $=$ German Society for Nutritional Medicine), Jauch KW, Kemen M, Hiesmayr JM, Horbach T, Kuse ER, Vestweber KH (ESPEN = European Society for Parenteral and Enteral Nutrition): ESPEN guidelines on enteral nutrition: surgery including organ transplantation. Clin Nutr 2006;25:224-244.

59 Brady M, Kinn S, Stuart P: Preoperative fasting for adults to prevent perioperative complications. Cochrane Database Syst Rev 2003:CD004423.

60 Nygren J, Thorell A, Jacobsson H, Larsson S, Schnell PO, Hylén L, Ljungqvist O: Preoperative gastric emptying. Effects of anxiety and oral carbohydrate administration. Ann Surg 1995;222:728-734.

61 Ljungqvist O, Nygren J, Thorell A: Insulin resistance and elective surgery. Surgery 2000;128:757-760.

62 Nygren J, Soop M, Thorell A, Sree Nair K, Ljungqvist O: Preoperative oral carbohydrates and postoperative insulin resistance. Clin Nutr 1999;8:117-120. 
63 Soop M, Nygren J, Myrenfors P, Thorell A, Ljungqvist O: Preoperative oral carbohydrate treatment attenuates immediate postoperative insulin resistance. Am J Physiol 2001;280:E576-E583.

64 Svanfeldt M, Thorell A, Hausel J, Soop M, Nygren J, Ljungqvist O: Effect of 'preoperative' oral carbohydrate treatment on insulin action - a randomised cross-over unblinded study in healthy subjects. Clin Nutr 2005;24: 815-821.

65 Nygren J, Soop M, Thorell A, Efendic S, Nair KS, Ljungqvist O: Preoperative oral carbohydrate administration reduces postoperative insulin resistance. Clin Nutr 1998;17: 65-71.

- 66 Henriksen MG, Hessov I, Dela F, Hansen HV, Haraldsted V, Rodt SA: Effects of preoperative oral carbohydrates and peptides on postoperative endocrine response, mobilization, nutrition and muscle function in abdominal surgery. Acta Anaesthesiol Scand 2003;47:191-199.

- 67 Yuill KA, Richardson RA, Davidson HI, Garden OJ, Parks RW: The administration of an oral carbohydrate-containing fluid prior to major elective upper gastrointestinal surgery preserves skeletal muscle mass postoperatively - a randomized clinical trial. Clin Nutr 2005;24:32-37.

-68 Hausel J, Nygren J, Thorell A, Lagerkranser $\mathrm{M}$, Ljungqvist O: Randomized clinical trial of the effects of oral preoperative carbohydrates on postoperative nausea and vomiting after laparoscopic cholecystectomy. Br J Surg 2005;92:415-421.

-69 Hausel J, Nygren J, Lagerkranser M, Hellström PM, Hammarqvist F, Almström C, Lindh A, Thorell A, Ljungqvist O: A carbohydrate-rich drink reduces preoperative discomfort in elective surgery patients. Anesth Analg 2001;93:1344-1350.

-70 Bisgaard T, Kristiansen VB, Hjortso NC, Jacobsen LS, Rosenberg J, Kehlet H: Randomized clinical trial comparing an oral carbohydrate beverage with placebo before laparoscopic cholecystectomy. Br J Surg 2004;91:151-158.

71 Smedley F, Bowling T, James M, Stokes E, Goodger C, O'Connor O, Oldale C, Jones P, Silk D: Randomized clinical trial of the effects of preoperative and postoperative oral nutritional supplements on clinical course and cost of care. Br J Surg 2004;91:983-990.

72 Rana SK, Bray J, Menzies-Gow N, Jameson J, Payne James JJ, Frost P, Silk DB: Short-term benefits of post-operative oral dietary supplements in surgical patients. Clin Nutr 1992;11:337-344.

-73 Keele AM, Bray MJ, Emery PW, Duncan HD, Silk DB: Two phase randomised controlled clinical trial of postoperative oral dietary supplements in surgical patients. Gut 1997; 40:393-399.
74 MacFie J, Woodcock NP, Palmer MD, Walker A, Townsend S, Mitchell CJ: Oral dietary supplements in pre- and postoperative surgical patients: a prospective and randomized clinical trial. Nutrition 2000;16:723-728.

75 Grant JP: On enteral nutrition during multimodality therapy in upper gastrointestinal cancer patients. Ann Surg 1995;221:325326.

-76 Garcia-de-Lorenzo A, Zarazaga A, GarciaLuna PP, Gonzalez-Huix F, López-Martínez J, Miján A, Quecedo L, Casimiro C, Usán L, del Llano J: Clinical evidence for enteral nutritional support with glutamine: a systematic review. Nutrition 2003;19:805-811.

77 Wilmore DW, Shabert JK: Role of glutamine in immunologic responses. Nutrition 1998; 14:618-626.

78 Evoy D, Lieberman MD, Fahey TJ, Daly JM Immunonutrition: the role of arginine. $\mathrm{Nu}$ trition 1998;14:611-617.

79 Reynolds JV, Daly JM, Zhang S, Evantash E, Shou J, Sigal R, Ziegler MM: Immunomodulatory mechanisms of arginine. Surgery 1988;104:142-151.

80 Daly JM, Reynolds J, Thom A, Kinsley L, Dietrick-Gallagher M, Shou J, Ruggieri B: Immune and metabolic effects of arginine in the surgical patient. Ann Surg 1988;208:512523.

81 Wu GH, Zhang YW, Wu ZH: Modulation of postoperative immune and inflammatory response by immune-enhancing enteral diet in gastrointestinal cancer patients. World J Gastroenterol 2001;7:357-362.

82 Alexander JW, Saito H, Ogle CK, Trocki O: The importance of lipid type in the diet after burn injury. Ann Surg 1986;204:1-8.

83 Kenler AS, Swails WS, Driscoll DF, DeMichele SJ, Daley B, Babineau TJ, Peterson MB, Bistrian BR: Early enteral feeding in postsurgical cancer patients: fish oil structured lipid-based polymeric formula versus a standard polymeric formula. Ann Surg 1996;223: 316-333.

84 Tsekos E, Reuter C, Stehle P, Boeden G: Perioperative administration of parenteral fish oil supplements in a routine clinical setting improves patient outcome after major abdominal surgery. Clin Nutr 2004;23:325330.

85 Daly JM, Weintraub FN, Shou J, Rosato EF Lucia M: Enteral nutrition during multimodality therapy in upper gastrointestinal cancer patients. Ann Surg 1995;221:327-338.

86 Gianotti L, Braga M, Nespoli L, Radaelli G, Beneduce A, Di Carlo V: A randomized controlled trial of preoperative oral supplementation with a specialized diet in patients with gastrointestinal cancer. Gastroenterology 2002;122:1763-1770.

87 Senkal M, Mumme A, Eickhoff U, Geier B, Späth G, Wulfert D, Joosten U, Frei A, Kemen M: Early postoperative enteral immunonutrition: clinical outcome and cost-comparison analysis in surgical patients. Crit Care Med 1997;25:1489-1496.
88 Braga M, Gianotti L, Vignali A, Carlo VD: Preoperative oral arginine and $n-3$ fatty acid supplementation improves the immunometabolic host response and outcome after colorectal resection for cancer. Surgery 2002; 132:805-814.

89 Braga M, Gianotti L, Nespoli L, Radaelli G, Di Carlo V: Nutritional approach in malnourished surgical patients: a prospective randomized study. Arch Surg 2002;137:174180.

90 Senkal M, Zumtobel V, Bauer KH, Marpe B, Wolfram G, Frei A, Eickhoff U, Kemen M: Outcome and cost effectiveness of perioperative enteral immunonutrition in patients undergoing elective upper gastrointestinal tract surgery: a prospective randomized study. Arch Surg 1999;134:1309-1316.

91 Braga M, Gianotti L, Radaelli G, Vignali A, Mari G, Gentilini O, Di Carlo V: Perioperative immunonutrition in patients undergoing cancer surgery: results of a randomized double-blind phase 3 trial. Arch Surg 1999; 134:428-433.

\$2 Xu J, Zhong Y, Jing D, Wu Z: Preoperative enteral immunonutrition improves postoperative outcome in patients with gastrointestinal cancer. World J Surg 2006;30:12841289.

$\checkmark 93$ Braga M, Vignali A, Gianotti L, Cestari A, Profili M, Di Carlo V: Immune and nutritional effects of early enteral nutrition after major abdominal operations. Eur J Surg 1996;162:105-112.

94 Gianotti L, Braga M, Gentilini O, Balzano G, Zerbi A, Di Carlo V: Artificial nutrition after pancreaticoduodenectomy. Pancreas 2000; 21:344-351.

95 Daly JM, Lieberman MD, Goldfine J, Shou J, Weintraub F, Rosato EF, Lavin P: Enteral nutrition with supplemental arginine, RNA, and omega- 3 fatty acids in patients after operation: immunologic, metabolic, and clinical outcome. Surgery 1992;112:56-67.

96 Gianotti L, Braga M, Vignali A, Balzano G, Zerbi A, Bisagni P, Di Carlo V: Effect of route of delivery and formulation of postoperative nutritional support in patients undergoing major operations for malignant neoplasms. Arch Surg 1997;132:1222-1229.

-97 Braga M, Vignali A, Gianotti L, Cestari A, Profili M, Di Carlo V: Benefits of early postoperative enteral feeding in cancer patients. Infusionsther Transfusionsmed 1995;22: 280-284.

98 Gianotti L, Braga M, Fortis C, Soldini L, Vignali A, Colombo S, Radaelli G, Di Carlo V: A prospective, randomized clinical trial on perioperative feeding with an arginine-, omega- 3 fatty acid-, and RNA-enriched enteral diet: effect on host response and nutritional status. J Parenter Enteral Nutr 1999; 23:314-320. 
-99 Farreras N, Artigas V, Cardona D, Rius X, 106 Braga M, Gianotti L, Vignali A, Di Carlo V: Trias M, Gonzalez JA: Effect of early postoperative enteral immunonutrition on wound healing in patients undergoing surgery for gastric cancer. Clin Nutr 2005;24: 55-65.

>100 Braga M, Gianotti L, Vignali A, Schmid A, Nespoli L, Di Carlo V: Hospital resources consumed for surgical morbidity: effects of preoperative arginine and omega-3 fatty acid supplementation on costs. Nutrition 2005;21:1078-1086.

-101 Plank LD, McCall JL, Gane EJ, Rafique M, Gillanders LK, McIlroy K, Munn SR: Preand postoperative immunonutrition in patients undergoing liver transplantation: a pilot study of safety and efficacy. Clin Nutr 2005;24:288-296.

-102 Lobo DN, Williams RN, Welch NT, Aloysius MM, Nunes QM, Padmanabhan J, Crowe JR, Iftikhar SY, Parsons SL, Neal KR, Allison SP, Rowlands BJ: Early postoperative jejunostomy feeding with an immune modulating diet in patients undergoing resectional surgery for upper gastrointestinal cancer: a prospective, randomized, controlled, double-blind study. Clin Nutr 2006;25:716-726.

103 Schilling J, Vranjes N, Fierz W, Joller H, Gyurech D, Ludwig E, Marathias K, Geroulanos S: Clinical outcome and immunology of postoperative arginine, omega-3 fatty acids, and nucleotide enriched enteral feeding: a randomized prospective comparison with standard enteral and low calorie/low fat intravenous solutions. Nutrition 1996; 12:423-429.

-104 Kemen M,SenkalM,Homann HH, Mumme A, Dauphin AK, Baier J, Windeler J, Neumann H, Zumtobel V: Early postoperative enteral nutrition with arginine-omega-3 fatty acids and ribonucleic acid-supplemented diet versus placebo in cancer patients: an immunologic evaluation of Impact. Crit Care Med 1995;23:652-659.

- 105 Giger U, Büchler M, Farhadi J, Berger D, Hüsler J, Schneider $H$, Krähenbühl $S$, Krähenbühl L: Preoperative immunonutrition suppresses perioperative inflammatory response in patients with major abdominal surgery - a randomized controlled pilot study. Ann Surg Oncol 2007;14:27982806.
Immunonutrition in gastric cancer surgical patients. Nutrition 1998;14:831-835.

107 Senkal M, Kemen M, Homann HH, Eickhoff U, Baier J, Zumtobel V: Modulation of postoperative immune response by enteral nutrition with a diet enriched with arginine, RNA, and omega-3 fatty acids in patients with upper gastrointestinal cancer. Eur J Surg 1995;161:115-122.

108 Braga M, Gianotti L, Cestari A, Vignali A, Pellegatta F, Dolci A, Di Carlo V: Gut function and immune and inflammatory responses in patients perioperatively fed with supplemented enteral formulas. Arch Surg 1996;131:1257-1264.

109 Matsuda A, Furukawa K, Takasaki H, Suzuki H, Kan H, Tsuruta H, Shinji S, Tajiri T: Preoperative oral immune-enhancing nutritional supplementation corrects Th1/ Th2 imbalance in patients undergoing elective surgery for colorectal cancer. Dis Colon Rectum 2006;49:507-516.

110 Nakamura K, Kariyazono H, Komokata T, Hamada N, Sakata R, Yamada K: Influence of preoperative administration of omega-3 fatty acid-enriched supplement on inflammatory and immune responses in patients undergoing major surgery for cancer. $\mathrm{Nu}$ trition 2005;21:639-649.

111 Tsujinaka T, Hirao M, Fujitani K, Mishima H, Ikenaga M, Sawamura T, Kurata M: Effect of preoperative immunonutrition on body composition in patients undergoing abdominal cancer surgery. Surg Today 2007;37:118-121.

112 Braga M: The Award for General Nutrition. Immunonutrition: from laboratory to clinical practice. Nutrition 2007;23:368-370.

113 Karen CM, Bruce RB: Immunonutrition: problematic or problem solving. Am J Clin Nutr 2003;77:764-770.

114 Silk DBA, Gow NM: Postoperative starvation after gastrointestinal surgery. BMJ 2001;323:761-762.

115 Sacks GS, Genton L, Kudsk KA: Controversy of immunonutrition for surgical criticalillness patients. Curr Opin Crit Care 2003; 9:300-305.

116 Heys SD, Walker LG, Smith I, Eremin O: Enteral nutritional supplementation with key nutrients in patients with critical illness and cancer: a meta-analysis of randomized controlled clinical trials. Ann Surg 1999; 229:467-477.
117 Kudsk KA: Immunonutrition in surgery and critical care. Annu Rev Nutr 2006;26: 463-479.

118 Heyland DK, Novak F, Drover JW, Jain M, Su X, Suchner U: Should immunonutrition become routine in critically ill patients? A systematic review of the evidence. JAMA 2001;286:944-953.

119 Windsor A, Braga M, Martindale R, Buenos R, Tepaske R, Kraehenbuehl L, Weimann A: Fit for surgery: an expert panel review on optimising patients prior to surgery, with a particular focus on nutrition. Surgeon 2004;2:315-319.

120 Bozzetti F, Gianotti L, Braga M, Di Carlo V, Mariani L: Postoperative complications in gastrointestinal cancer patients: the joint role of the nutritional status and the nutritional support. Clin Nutr 2007;26:698709.

$>121$ Lassen K, Dejong CH, Ljungqvist O, Fearon $\mathrm{K}$, Andersen J, Hannemann P, von Meyenfeldt MF, Hausel J, Nygren J, Revhaug A: Nutritional support and oral intake after gastric resection in five northern European countries. Dig Surg 2005;22:346-352.

$>122$ Lassen K, Hannemann P, Ljungqvist O, Fearon K, Dejong CHC, von Meyenfeldt MF, Hausel J, Nygren J Andersen J, Revhaug A: Patterns in current perioperative practice: survey of colorectal surgeons in five northern European countries. BJM 2005; 330:1420-1421.

123 Kehlet H, Wilmore DW: Fast-track surgery. Br J Surg 2005;92:3-4.

124 Nygren J, Thorell A, Ljungqvist O: New developments facilitating nutritional intake after gastrointestinal surgery. Curr Opin Clin Nutr Metab Care 2003;6:593-597.

125 Anderson AD, McNaught CE, MacFie J, Tring I, Barker P, Mitchell CJ: Randomized clinical trial of multimodal optimization and standard perioperative surgical care. Br J Surg 2003;90:1497-1504.

$>126$ Cerfolio RJ, Bryant AS, Bass CS, Alexander JR, Bartolucci AA: Fast tracking after Ivor Lewis esophagogastrectomy. Chest 2004; 126:1187-1194. 